\title{
Looking for lament in the Church of Scotland: Theological opposition and liturgical alternatives
}

\section{Malcolm Gordon}

In the aftermath of the Dunblane massacre in Scotland in 1996, one minister confessed to John Bell of the Iona Community at a clergy conference shortly after, 'It was on that Sunday that I realised we had lost the ability to lament.' ${ }^{1}$ But when did that loss take place? This article will trace the theological roots of the loss of lament within the Church of Scotland, guided in part by the work of Nicholas Wolterstorff to briefly consider the liturgical legacies of Augustine and Calvin, before examining the work of Millar Patrick as a representative of Presbyterian theology and liturgy during the mid-twentieth century. Of particular interest is how response to suffering was embodied in Presbyterian liturgy around the time of the Second World War (WW2). Was the response recognisable as lament as the Bible presents it or were other trajectories already in place?

\section{Lament: a definition}

Lena-Sophia Tiemeyer defines lament at its simplest as an 'expression of pain, sorrow and grief.' ${ }^{2}$ She goes on to state that an element of complaint is consistently in view when biblical lament is considered. ${ }^{3}$ Complaint implies that things are not as they should be. Walter Brueggemann agrees with this, claiming that it is both the starting place and central concern of lament that 'Life isn't right.' ${ }^{4}$ Furthermore, a complaint must be directed at someone, ideally someone who can do something about it. Brueggemann outlines four distinctive elements for biblical lament: 
1. Things are not right in the present arrangement.

2. They need not stay this way but can be changed.

3. The speaker will not accept them in this way, for it is intolerable.

4. It is God's obligation to change things. ${ }^{5}$

To this I would add the voice of contemporary Scottish theologian, John Swinton. He writes, 'Lament suggests that the person who is lamenting has a genuine grievance'. ${ }^{6}$ Also, the nature of God's sovereignty will be questioned in the course of lament, as Brueggemann insists that lament keeps, 'all power relations under review and capable of redefinition. ${ }^{7}$ It also means, as biblical scholar Donald Moffat points out, that human sinfulness does not impede or rule out the practice of lament, as lament assumes that sin is being dealt with within the covenantal arrangements between God and his people. ${ }^{8}$ Within the framework of biblical lament therefore, sin does not derail or preclude lament. Finally, Brueggemann notes that while all lament is directed at God, for it is a liturgical act, it is not necessarily about God. The focus of the complaint can either be directed at fellow humans (for example enemies or the wicked), or be about God Himself. ${ }^{9}$

Lament, therefore, essentially enlarges the playing field in which conversation with God can take place. It gives words for the moments of life when we are left speechless and dumbfounded. Swinton writes, 'Lament provides us with a language of outrage that speaks against the way things are, but always in the hope that the way things are just now is not the way they will always be. Lament is thus profoundly hopeful. ${ }^{10}$ Swinton goes on to enlist Stanley Hauerwas, who argues that lament is an act that enables the naming of the silence that suffering creates. It provides an act of meaning in the face of something otherwise meaningless, and paradoxically enables faithful living in the very moment when faith seems most threatened. ${ }^{11}$

As we will discover, these features of biblical lament do not feature within the Presbyterian theological heritage; this would impact the nature of liturgical resources used in response to the trauma and tragedy of WW2. 


\section{Losing lament}

The theologian Nicholas Wolterstorff, with Reformed roots and sharp insight in the field of liturgics, has done much to draw attention to the lack of lament in Christian worship. He has outlined why a number of major traditions of Christian theology have 'stifled' lament. ${ }^{12}$

Wolterstorff starts with Augustine who in Confessions recalls how, before his conversion, he grieved uncontrollably over the death of his closest friend while, after his conversion, he was again given over to ungovernable grief after the death of his mother, grief that Augustine considered inappropriate. Wolterstorff writes that Augustine saw his grief as evidence that he was guilty of "too much worldly affection." ${ }^{13}$ This idea was built upon Augustine's utilitarian view of the created world, which was to be used but not enjoyed because God alone was to be humanity's source of joy. ${ }^{14}$ Wolterstorff writes of Augustine's theology, 'Grief, though not itself precisely sinful, is the mark, the sign, of sinful orientation of life. In Augustinian piety, lament is displaced by confession of sins.' ${ }^{15}$ The suggestion is that if we find lament lacking and confession and penitence in its place as a response to suffering then Augustine's work may be at its root.

Such an emphasis is precisely what we discover in John Knox's Liturgy, the first Book of Common Order of the Church of Scotland, which remained profoundly influential even into the twentieth century. Rev John Wilson Baird, addressing the Scottish Church Service Society in 1948, said of Knox's Liturgy: 'It is not a book on which we can look back with much pride. It is violent and unseemly in much of its language. ${ }^{16}$ But Baird's assessment was not necessarily the prevailing view. An article in the Church Service Society Annual, for example, detailed a church service in the mid-1950s that was based, in part, on Knox's Liturgy ${ }^{17}$ Moreover, in 1941, Principal John Dickie recommended Knox's Liturgy to ministry students at Knox Theological Hall in Dunedin, New Zealand as a good guide for how to form prayer in a time of war. ${ }^{18}$

In Knox's Liturgy we encounter a spirituality in which confession and penitence are the primary forms by which God is accessed. This penitential focus is not merely reserved for times of suffering but is employed at all times. Confession precedes the central ways in which 
God is encountered through Word and Sacrament. In the general section describing the "Order of Public Worship" no less than four prayers of confession are provided for the first half of the service. No other form of prayer is offered before the sermon: no Call to Worship, Adoration, or Assurance of Pardon. ${ }^{19}$

The prayer offered for use before the sermon carries the following title, "A Confession of Sins, and Petitions made unto God in the time of our extreme Troubles, and yet commonly used in the Churches of Scotland before the Sermon." ${ }^{20}$ The prayer is heavily penitent in tone, stating, 'our hearts confessing that justly Thou hast punished us by the tyranny of strangers ...'21 before seeking God's forgiveness and deliverance. Donald Moffat points out that by the Second Temple Period in Israel, following the Babylonian exile, penitence had overtaken lament as the correct response to suffering, whether it was thought to be deserved or not. ${ }^{22}$ The system of temple sacrifices, which was the mechanism for dealing with sin, was seen to have failed as it had not been able to address the magnitude of the people's failings. A new category of human brokenness was created in the theological imagination of the Jewish people, one that could only be dealt with by contrition and penitence. Therefore lament no longer had freedom to be voiced, because the question of sin was considered unresolved. It seems the same can be said of the Scottish Reformed movement.

Following already lengthy prayers of confession, we find this closing note on the "Order of Public Worship",

It shall not be necessary for the Ministers daily to repeat all these things before mentioned, but, beginning with some manner of confession, to proceed to the Sermon, which ended, he either useth the Prayer for all Estates before mentioned, or else prayeth, as the Spirit of God shall move his heart, framing the same according to the time and matter which he hath entreated of. And if there be at any time any present plague, famine, pestilence, war, or suchlike, which be evident tokens of God's wrath, as it is our part to acknowledge our sins to be the occasion thereof, so are we appointed by the Scriptures to give ourselves to mourning, fasting, and prayer, as the means to turn away God's heavy displeasure. ${ }^{23}$ [Emphasis mine]. 
Not only do we find Augustine's emphasis on confession enshrined here in Presbyterian piety, but in Knox's Liturgy it has developed something of a punitive edge.

Wolterstorff next turns his attention to Calvin who parts company somewhat with Augustine in his view of the world, instead endorsing our embodied state as intrinsic to a Christian way of being. Calvin writes,

[...] thus, afflicted by disease, we shall both groan and be uneasy and pant after health; thus pressed by poverty we shall be pricked by the arrows of care and sorrow; thus we shall be smitten by the pain of disgrace, contempt, injustice; thus at the funerals of our dead ones we shall weep the tears that are owed to our nature. ${ }^{24}$

Whilst Augustine viewed creation as the 'works of God', from which we are to deflect our attention away and so toward our creator, Calvin saw creation as the multifaceted 'gift of God', not to be valued for its mere usefulness, but for enjoyment's sake as well. ${ }^{25}$ What then does this talk about enjoyment of creation have to do with our response to suffering? Calvin had such a high view of the sovereignty of $\mathrm{God}^{26}$ that our sufferings were to be understood as part of God's gift to us. ${ }^{27}$ He writes,

[This] general axiom is to be maintained, that all the suffering to which human life is subject and liable are necessary exercises by which God partly invites us to repentance, partly instructs us in humility, and partly renders us more cautious and more attentive in guarding against the allurements of $\sin$ for the future. ${ }^{28}$

For Calvin, the primary posture of response was not confession of sin (although that was a part of it), but patience, forbearance and, ultimately, gratitude.

Traces of Calvin's legacy within the liturgical expression of the Church of Scotland around the time of WW2 are found in Prayers for Divine Service. This volume was published in 1923 and used while the 1940 edition of the Book of Common Order was being compiled. What is striking is the somewhat confused theology around suffering. 
The opening prayer in the chapter, "Prayers for the Sick and Afflicted" begins with the words, 'O God, most merciful Father, Who dost not willingly grieve nor afflict the children of men' before going on to say, 'Give him a sure and abiding faith, that he may possess his soul in patience, and may bear with submission any further trial Thou mayst see good to send. ${ }^{29}$ It would seem fair to ask, well which is it? Is God either unwilling to afflict His people, or is God the One sending these trials?

Repeatedly, the call to submission in the face of suffering rings through these prayers. The heavily penitent tone of Knox's Liturgy and Calvin's notion of suffering as corrective punishment are alive and well in sentiments like, 'let Thy chastening, though for the present grievous, yield in them afterwards the peaceable fruits of righteousness' ${ }^{30}$ This in a prayer for someone suffering a long-term illness no less! The dominant tone of these prayers towards suffering is one of acceptance that outward suffering will result in inward sanctification and reward. The person suffering 'deep dejection of the Spirit' (likely what we would call depression) is encouraged through the prayer, 'that all things work together for his good, and that his present affliction which is but for a moment, worketh for him a far more exceeding and eternal weight of glory'. ${ }^{31}$ Calvin saw the world as 'a vast reformatory' ${ }^{32}$ where suffering was one of the tools God used to refine and remake us. Consequently, the only remaining liturgical posture was one of grateful patience while God's plan inevitably unfolded, as embodied in these prayers. Prayers like these left little room for meaningful response from God or from those suffering, as (like Brueggemann suggested happens when lament is abandoned) they tended to shut down the Divine-human conversation rather than open it up.

\section{Alternative responses to suffering}

What then, of the theologians and liturgists who lived and breathed during the period of WW2 itself? How did they invite people to understand and respond to the suffering it brought?

In looking for a representative of this era, we will consider the work of one of the leading liturgical minds at the time, Rev Dr Millar Patrick. Patrick was described in an article in the Church Service 
Society Annual as 'our greatest living authority on the music of the Church. ${ }^{33}$ A United Presbyterian minister, he was deeply involved in forming the 1928 Book of Common Order for that church (which was later adopted for use in the newly-reformed Church of Scotland), as well as the Revised Church Hymnary (1927) and Psalter (1929). His influence on the shape of worship in the Presbyterian world around the middle of the twentieth century cannot be overstated. In his book, Four Centuries of Scottish Psalmody, published in 1949, he argued that a number of the psalms 'were never intended to be sung [having] Judaic imagery [...] quite alien to modern ideas [and a] theology and ethic [...] out-dated by the Christian revelation. ${ }^{34}$ In an earlier indication of this approach, an index in the 1929 Psalter recommending the most suitable metrical psalms for congregational worship left sixty-five psalms out altogether. ${ }^{35}$ Of those sixty-five, thirty-eight of them were psalms of lament. Whilst twenty-seven lament psalms were included, almost all were so heavily redacted as to barely correlate to their original states.

To illustrate the shape and the significance of Patrick's edits, two psalms that are short enough to have been used in full are offered here. Take for example the only imprecatory psalm that is included in the index recommendations, Psalm 137. I have included the full text of the Psalter's version, with the excluded verses struck out.

1. By Babel's streams we sat and wept, when Zion we thought on.

2. In midst thereof we hanged our harps the willow-trees upon.

3. For there a song required they, who did us captive bring:

Our spoilers called for mirth, and said, A song of Zion sing.

4. O how the Lord's song shall we sing within a foreign land?

5. If thee, Jerus'lem, I forget, skill part from my right hand.

6. My tongue to my mouth's roof let cleave, if I do thee forget, 
Jerusalem, and thee above my chief joy do not set.

7. Remember Edom's children, Lord, who in Jerus'lems day, Ev'n unto its foundation, Raze, raze it quite, did say.

8. O daughter thou of Babylon, near to destruetion; Blessed shall he be that thee rewards, as thou to us hast done.

9. Yea, happy surely shall he be thy tender little ones Who shall lay hold upon, and them shall dash against the stones. ${ }^{36}$

While the anguish of the original psalm is allowed to survive, the anger is left out. Whereas the selection finishes with a reproach toward the psalmist if they should forget God, the original instead demanded that God remember the evil done to His people (vv. 7-8), before the infamous hope of seeing their vicious revenge (v. 9). Perhaps given the emotional restraint that typified this period it is not so surprising to see such a vitriolic ending edited out. ${ }^{37}$ Cultural and theological factors seem to blur somewhat in Patrick's stance.

Psalm 43 represents another redaction that threatens the original's meaning. The index suggests opening the psalm with v. 3, ' $\mathrm{O}$ send thy light forth and thy truth' which might be satisfying at a poetical level, but it lacks the theological and pastoral power of the original, which implies that God is somehow responsible for the trouble that besets the psalmist. V. 2 implores, 'why thrusts thou me thee fro'?' While clarity of meaning may be lost in its archaic rendering, the woundedsounding, 'Why have you rejected me?' of a more contemporary translation has impact. ${ }^{38}$

The practice of selecting particular verses from Psalms for reasons of contemporary theological and cultural logic seems to have been well established, and was noted at the time by Herbert Wiseman, a Music Director, church organist and member of the Scottish Church Service Society. He wrote, 
It will only be necessary for an impartial enquirer to open his metrical psalter and to read carefully through the psalms $[\ldots]$ to find that there are whole tracts of unexplored country, not only for him but for every congregation in the land. We Scots have carefully selected certain passages from the Psalms, and though we sing these very often, we separate them from their context. ${ }^{39}$

As a result, Wiseman wrote, "we are not "Psalm-singers," but only singers of snippets of Psalms. ${ }^{40}$ Writing in 1941-42, he went on to provide a remarkably apt quote given the scope of this article.

Now, it is admitted even by lovers of "The Book of Psalms" that a certain number of the "blood-thirsty" type should be eliminated from Christian worship (some of these would, however, give an opportunity for a wholesome venting of feelings in these days of War-stress!) but there can be no such question that in this book we have the greatest heritage of church-song that has been bequeathed to us from bygone ages. How can we use it to the full? ${ }^{41}$ [Emphasis mine].

Wiseman's concern about the loss of the Psalter as a whole was not imagined. That a large number of psalms were left unsung, and that a large number of verses were left out from those that were sung is attested to in indices of the time. ${ }^{42}$ Yet, Patrick's goal may well have been to create a canon within the canon of the Psalms, one which largely excluded lament. He went so far as to suggest that future Psalters should only include the most popular of the metrical psalms, for, 'There is no point in continuing to print, for mere custom's sake, so much which everyone knows will never be sung', ${ }^{43}$

Was Patrick's treatment of the lament psalms limited to him and the index at the back of the Psalter? Sadly no. The Church of Scotland's own Book of Common Order (1940) further entrenched this approach in a number of ways. Firstly, when recommending psalms of lament for use in Burial services, verse selections were used with telling effect. Following the general Burial service (which also contains redacted lament psalms in its recommendations) there is a special 
service included for use on the occasions of tragic death. ${ }^{44}$ The service opens with Psalm 130, unreferenced and with key verses removed.

\section{Psalm 130 (KJV)}

1. Out of the depths have I cried unto thee, O LorD.

2. Lord, hear my voice: let thine ears be attentive to the voice of my supplications.

3. If thou, LORD, shouldest mark iniquities, O LORD, who shall stand?

4. But there is forgiveness with thee, that thou mayest be feared.

5. I wait for the LoRD, my soul doth wait, and in his word do I hope.

6. My soul waiteth for the LORD more than they that wateh for the morning: I say, more than they that wateh for the morning.

7. Let Israel hope in the LORD: for with the LORD there is mercy, and with him is plenteous redemption.

8. And he shall redeem Israel from all his iniquities.

While the verses excluded do not represent a large part of the psalm, their loss is significant. While they do not contain the more desperate or violent language often removed from these psalms to sanitise them, they do portray a hope that is not yet fulfilled. Psalm 130 in its original state does not resolve; it begins and ends with God being absent. The psalmist is crying out in vv. 1-2, and waiting and hoping in v. 5 . The waiting and watching continues in the excluded v. 6 (and the repetition of 'more than they that watch for the morning' reveals that this is the true climax of the psalm). But while v. 7 encourages those who wait to trust in the goodness of God, the exhortation to 'hope in the Lord' is edited out, presumably because 'hope' implies that God's goodness has not yet arrived. The closing verse, with its future tense, '[The LORD] shall redeem' is removed altogether. From a lament psalm that begins with a lack of hope and the seeming absence of God, and originally ends with the kindling of hope whilst still in the seeming absence of God, the editors of the Book of Common Order (1940) have thus cobbled together a psalm with a contrived kind of resolution. The preface of this volume claims, 
[...] the Church of Scotland, adhering to the Scottish Reformation and receiving "the Word of God which is contained in the Scriptures of the Old and New Testaments as its supreme rule of faith and life," bases all its worship on Holy Scripture. Without reservation of any kind it may be asserted that everything contained in this Book receives its warrant from that source.

However, given the methodical expunging of lament demonstrated here, perhaps the claim would be stronger if it said that this worship is based on parts of Holy Scripture, namely the parts deemed acceptable and appropriate.

The claim of the Book of Common Order (1940) looks more tenuous still when the lectionary included in it is explored. Across a biennial cycle of morning and evening services, 120 whole psalms are suggested, with two further offered as selections. Of the 30 excluded (in whole or in part) almost two-thirds are laments. Of the lament psalms that are included, the most popular are the penitential psalms, which blend confession with a petition for God to intervene. The Presbyterian tendency established in Knox's Liturgy, built upon Augustine's preference for confession in place of lament, seems present here. Even accounting for the loss of almost twenty lament psalms in total from the lectionary, those that are included feature less often than all other psalms. ${ }^{45}$

\section{A costly loss?}

Despite lament forming a vital part of the spirituality of the ancient Jewish people, as represented in the Book of Psalms, there is a profound lack of lament in the life of the contemporary church. This loss has not occurred overnight; its roots stretch back to the very beginnings of Christendom, as evidenced in in the work of Augustine. Brueggemann has claimed that the absence of lament in the life of the church reduces the great dialogue of worship into mere acquiescence on the part of humanity, whose right to question the status quo has been removed, and in fact reduces God to being a mere proxy for the status quo. ${ }^{46}$ Wolterstorff sees a failure to lament as something of a surrender to evil, claiming, 'God is not satisfied when ninety-nine of the one hundred 
are safely in the corral. ${ }^{97}$ The inference is that we ought not to be any more easily satisfied with the state of our world and that lament is the vehicle for voicing this protest. The inability of the Presbyterian church to express any meaningful protest to the experience of WW2 before God seems to be evidence of the acquiescence and fatalism that Brueggemann and Wolterstorff warn against. Arguably the church was left with an impoverished and inadequate vocabulary during a period of appalling suffering, just when it needed to be able to name outrage and hope, those acts of meaning enabling faithful living that lament offers.

\section{Conclusion}

Tracing back to the theological roots of the Presbyterian movement, this article has sought to show how lament has struggled for air in such an atmosphere. Augustine's emphasis on confession rather than lament was picked up in Knox's Liturgy with zeal, and Calvin's emphasis on patience and gratitude can be seen in the prayer resources offered for those undergoing suffering and trials. Ultimately these inheritances are strongly represented in Millar Patrick's stance that lament does not belong within Christian worship, to the point that we ought to save ourselves the trouble of printing these psalms at all. This theology was worked out efficiently across the Church of Scotland's major liturgical resources during this period, namely its Hymnary, Psalter and Book of Common Order, precisely at a moment in human history when people needed to express their grief and pain to God, so that their complaint could ground and empower faith beyond loss.

\section{Notes}

1 John Bell, uncited magazine article, in Paul Bradbury, Sowing in Tears: How to Lament in a Church of Praise (Cambridge: Grove Books, 2007), 3.

2 Lena-Sofia Tiemeyer, "The Doubtful Gain of Penitence: The Fine Line between Lament and Penitential Prayer", in Spiritual 
Complaint: The Theology and Practice of Lament, ed. Miriam J. Bier and Tim Bulkeley (Eugene, Or.: Pickwick Publications, 2013), 102.

3 Ibid.

4 Walter Brueggemann, "The Costly Loss of Lament", Journal for the Study of the Old Testament 36 (1986): 62.

5 Ibid.

6 John Swinton, Raging with Compassion: Pastoral Responses to the Problem of Evil (Grand Rapids, Mich.: Wm. B. Eerdmans, 2007), 104.

7 Brueggemann, "The Costly Loss of Lament", 59.

8 Donald P. Moffat, "The Profit and Loss of Lament: Rethinking Aspects of the Relationship between Lament and Penitential Prayer", in Bier and Bulkeley, Spiritual Complaint, 96.

9 Brueggemann, The Costly Loss of Lament, 62.

10 Swinton, Raging with Compassion, 105.

11 Stanley Hauerwas, Naming the Silences: God, Medicine, and the Problem of Suffering (Grand Rapids, Mich.: Wm. B. Eerdmans, 1990), 182. Cited in John Swinton, Raging with Compassion, 106.

12 Nicholas Wolterstorff, "If God is Good and Sovereign, Why Lament?", Calvin Theological Journal 36 (2001): 42-52.

13 Ibid., 46.

14 Ibid.

15 Ibid.

16 John Wilson Baird, "Second Thoughts on the Book of Common Order", Church Service Society Annual 19 (1949): 3.

17 Ronald Selby Wright, "Peace and Safety", Church Service Society Annual 25 (1955): 11. It also noted the 1940 Book of Common Order as well as other resources.

18 John Dickie, "Statement on Prayer in Wartime", unpublished lecture notes, Knox Theological Hall, Presbyterian Research Centre, Dunedin, New Zealand (1941), 2.

19 The Book of Common Order of the Church of Scotland, commonly known as John Knox's Liturgy. Historical introduction and illustrative notes by the Rev G. W. Sprott (Edinburgh: William Blackwood and Sons, 1901), 81. 
Ibid., 87.

21 Ibid.

22 Moffat, The Profit and Loss of Lament, 90.

23 Knox's Liturgy, 92.

24 John Calvin, Institutes of the Christian Religion, ed. John T. McNeill, trans. Ford Lewis Battles (Philadelphia: Westminster Press, 1960), III.viii.10. Cited in Wolterstorff, "If God is Good and Sovereign", 47.

25 Wolterstorff, "If God is Good and Sovereign", 47.

26 John Calvin, Institutes of the Christian Religion, vol. 1, trans. Henry Beveridge (London: James Clarke \& Co., 1957), 173. Calvin writes,

If one falls among robbers, or ravenous beasts; if a sudden gust of wind at sea causes shipwreck; if one is struck down by the fall of a house or a tree; if another, when wandering through desert paths, meets with deliverance; or, after being tossed by the waves, arrives in port, and makes some wondrous hairbreadth escape from death - all these occurrences, prosperous as well as adverse, carnal sense will attribute to fortune. But whoso have learned from the mouth of Christ that all the hairs of his head are numbered (Matth. x. 30), will look farther for the cause, and hold that all events whatsoever are governed by the secret counsel of God. (I.xvi.2)

27 It should not be inferred from this theological stance that Calvin lived a life free of suffering. Quite the opposite. He suffered religious persecution and had to flee his native France as a refugee. He was later driven from his adopted home of Geneva before being asked to return. His family life was also marked with tragedy, his only son was born prematurely and died shortly afterwards, then his beloved wife Idelette suffered ill health until she died several years later. See T. H. L. Parker, John Calvin: A Biography (London: Dent, 1975), 30f., 65f., 102.

28 John Calvin, Commentaries on the First Book of Moses called Genesis, vol. 1, trans. John King (Grand Rapids, Mich.: Baker Press, 1979), 179. Cited in Wolterstorff, "If God is Good and Sovereign", 48. 
29 Church of Scotland Committee on Aids to Devotion, Prayers for Divine Service in Church and Home (Edinburgh: William Blackwood, 1923), 171f.

30 Ibid., 174.

31 Ibid., 177.

32 Wolterstorff, "If God is Good and Sovereign", 49.

33 Herbert Wiseman, "Tercentenary of the Scottish Psalter of 1635", Church Service Society Annual 7 (1934-35): 26.

34 Millar Patrick, Four Centuries of Scottish Psalmody (London: Oxford University Press, 1949), 227.

35 Church of Scotland, Revised Church Hymnary: Music Edition (London: Oxford University Press, 1927), 263-68.

36 Church of Scotland, The Scottish Psalter and Church Hymnary, Revised Edition (London: Oxford University Press, 1929), 80 .

37 Lucy Noakes writes,

Grief and war, which so often go hand in hand, are two of the most disruptive and disturbing of events that we can experience: both promise the disordering of previous expectations, certainties, and ways of life and both can unravel our sense of self, of who we are. The two total wars of the twentieth century nonetheless demanded of their participants, both civilian and military, that grief be carefully managed. Good wartime citizenship depended, in large part, on a stoical acceptance of suffering.

[Lucy Noakes, "Gender, Grief, and Bereavement in Second World War Britain", Journal of War \& Culture Studies 8 (2015): 73.] 263-68.

43 Patrick, Four Centuries of Scottish Psalmody, 230.

Psalm 43:2 TNIV. Annual 12 (1941-42): 9.

Ibid.

Ibid., 10.

Herbert Wiseman, "The Book of Psalms", Church Service Society

Church of Scotland, Revised Church Hymnary: Music Edition, 
44 Presbyterian Church of South Africa, Service Book and Ordinal of the Presbyterian Church of South Africa (Glasgow: MacLehose, Jackson \& Co. for the Church Service and Aids to Devotion Committee of the General Assembly, 1928), 99. Interestingly this service, borrowed from the South African Presbyterian Church's Service Book and Ordinal, was included under the heading of a Burial service for use in cases of suicide.

45 Lament psalms feature 1.7 times as opposed to all other psalms featuring 2.13 times per cycle.

46 Brueggemann, "The Costly Loss of Lament," 60.

47 Wolterstorff, "If God is Good and Sovereign", 50. 